\title{
Penyuluhan Motivasi Minat Siswa Untuk Melanjutkan Pendidikan Ke Perguruan Tinggi - SMK FAJAR Ciseeng Bogor
}

\author{
Edi Mulyanto, Jumino \\ Program Studi Pendidikan Ekonomi , Universitas Pamulang,Tangerang Selatan \\ dosen 01755@unpam.ac.id, dosen 01803@ unpam.ac.id,
}

Naskah diterima: tanggal bulan tahun, direvisi: tanggal bulan tahun, disetujui: tanggal bulan tahun

\begin{abstract}
Abstrak
Dari hasil investigasi lapangan di SMK FAJAR - Ciseeng Bogor, diketahui sebagian besar siswa yang berada di SMK Kelas 12 (yang akan lulus di tahun 2021), mereka belum memiliki wacana atau alternatif untuk melanjutkan ke Perguruan Tinggi. Hal ini terdapat beberapa faktor, : kondisi ekonomi orang tua dan lingkungan. Faktor lingkungan dan pergaulan teman sebaya merupakan faktor yang dominan, karena setelah lulus SLTA langsung bekerjagai Supermarket, Pertokoan dan Restauran yang tersebar di wilayah Bogor dan sekitarnya, jika fenomena ini dibiarkan akan menjadi tradisi yang turun temurun. PKM ( Pengabdian Kepada Masyarakat) ini bertujuan untuk merubah paradigma pada siswa dengan memberikan motivasi dan dobrakan perubahan, diharapkan dimasa yang akan datang khususnya di wilayah Ciseeng Bogor tidak hanya lulus SLTA namun dapat melanjutkan ke Perguruan Tinggi, dengan metode yang digunakan yaitu penyuluhan dan berdiskusi dengan para peserta. Kegiatan berjalan dengan lancar dan mendapat tanggapan positif dari Pimpinan SMK FAJAR dan terlihat bahwa siswa-siswi mengikuti dengan baik dan mereka nampak begitu antausias. Kegiatan ini dapat menjadi informasi berharga bagi siswa-siswi yang ternyata selama ini belum mereka dapatkan. Diharapkan kegiatan ini akan dapat merangsang mereka setelah lulus, untuk melanjutkan pendidikan ke jenjang pendidikan tinggi.
\end{abstract}

Kata Kuncinya : Motivasi, Melanjutkan Pendidikan, Perguruan Tinggi.

\begin{abstract}
From the results of field investigations at FAJAR Vocational School - Ciseeng Bogor, it is known that most students in Class 12 Vocational High School (which will graduate in 2021), they do not yet have a discourse or alternative to continue to Higher Education. This is due to several factors: the economic condition of parents and the environment. Environmental factors and peer association are the dominant factors, because after graduating from high school, they immediately work in Supermarkets, Shops and Restaurants spread across Bogor and surrounding areas, if this phenomenon is allowed to continue it will become a hereditary tradition. This PKM (Community Service) aims to change the paradigm of students by providing motivation and breakthrough changes, it is hoped that in the future, especially in the Ciseeng - Bogor area, they will not only graduate from high school but can continue to university, with the methods used, namely counseling and discussion. with the participants. The activity went smoothly and received a positive response from the leadership of FAJAR Vocational School and it was seen that the students followed well and they seemed very enthusiastic. This activity can be valuable information for students that they have not received so far. It is hoped that this activity will stimulate them after graduation to continue their education to higher education.
\end{abstract}

Keywords : Motivation, Continuing Education, Higher Education. 


\section{PENDAHULUAN}

Minat untuk melanjutkan pendidikan ke jenjang perguruan tinggi menjadi motivasi awal seorang siswa untuk mewujudkan citacitanya menjadi seorang sarjana. Tanpa adanya minat, maka sulit kesadaran itu timbul dari dalam diri siswa yang bersangkutan. Pentingnya minat akan mendorong motivasinya menempuh perjuangan tanpa dipengaruhi terlebih dahulu oleh orang lain. Menurut Slameto (2015:180) dijelaskan bahwa minat itu merupakan kondisi rasa lebih suka dan rasa ketertarikan pada suatu hal atau aktivitas, tanpa adanya yang menyuruh. Menurut Astuti, M.O dkk (2019), dikatakan bahwa minat berarti suatu kondisi yang terjadi jika seseorang melihat ciri-ciri atau arti sementara situasi yang bisa dihubungka dengan keinginan dan kebutuhan bagi dirinya sendiri. Sehingga apa yang telah dilihat oleh seseorang bisa membangkitkan minatnya tergantung pada adanya hubungan dengan kepentingannya sendiri. Adanya suatu ketertarikan yang sifatnya tetap di dalam diri subjek atau seseorang yang sedang mengalaminya atas suatu bidang atau hal tertentu dan adanya rasa senang terhadap bidang atau hal tersebut, sehingga seseorang mendalaminya. Semakin kuat atau dekat hubungan tersebut, semakin besar minat yang muncul.
Perkembangan ilmu pengetahuan dan teknologi yang begitu cepat pada saat ini, menuntut dunia usaha menyesuaiakan diri dengan perkembangan jaman dan peradaban kehidupan yang semakin modern. Kini kebutuhan sumber daya manusia yang terampil dan memiliki pengetahuan tidak dapat dielakkan lagi. Namun sumber daya manusia yang terampil dan memiliki pengetahuan cukup, ini semua bukanlah hal yang secara instan dan mudah begitu saja dapat diperoleh, namun perlu adanya pengorbanan dan upaya serta usaha, harus dengan menambah kemampuan dan integritas. Satu-satunya untuk dapat memenuhi kebutuhan sumber daya manusia yang terampil dan memiliki pengetahuan yang baik, hanya dapat diperoleh melalui pendidikan tinggi atau melanjutkan Pendidikan ke jenjang Perguruan Tinggi. Lulusan SLTA masih belum cukup mampu untuk memenuhi kebutuhan tuntutan dunia usaha yang semakin modern dan meninggalkan cara-cara lama yang dianggap sudah manual, masih konvensional dan ketinggalan jaman, oleh karena itu tuntutan baik yang bergerak di sektor swasta atau dunia usaha maupun pemerintaan harus sudah mengikut teknologi yang serba otomatis dan digital, karena ini semua akan berdampak terhadap efisiensi dan efektifitas operasional yang dibutuhkan baik dunia 
usaha maupun di Instansi Kepemerintahan. Perguruan Tinggi merupakan solusi bagi siswa untuk dapat menambah ilmu pengetahuan dan keterampilan mereka guna memenuhi kebutuhan sumber daya manusia di dunia usaha saat ini dan yang akan datang. Disadari bahwa minimnya wawasan dan pengetahuan yang dimiliki siswa terhadap informasi pendidikan tinggi, juga menjadi suatu kendala bagi siswa untuk melanjutkan pendidikan ke perguruan tinggi. Penyuluhan tentang informasi perguruan tinggi yang mereka pilih juga dipengaruhi oleh kemampuan ekonomi yang dimiliki setiap siswa. Diharapkan jika siswa memiliki informasi yang cukup, mereka akan mulai terbangun keiinginan untuk dapat melanjutkan pendidikan yang tentunya disesuaikan dengan kondisi ekonomi mereka.

Dari hasil investigasi lapangan di SMK FAJAR - Ciseeng Bogor, yang berlokasi di pinggiran kota, tentunya banyak hal-hal yang perlu harus dilakukan peningkatan edukasi terhadap para siswanya untuk lebih meningkatkan wawasan dan pola pikir yang lebih moderen dan menatap masa depan yang lebih baik lagi. Oleh karena itu pada saat dilakukan kunjungan diketahui bahwa mayoritas dari siswa di SMK tersebut belum memiliki wacana atau alternative dalam rencna untuk melanjutkan ke jenjang
Perguruan Tinggi. Fenomena ini sudah tidak asing lagi dan hal yang lumrah bahwa dalam daerah pinggiran kota merupakan mayoritas yang terjadi dalam masyarakat, di mana hal ini disebabkan karena : kondisi ekonomi orang tua atau keluarga yang kurang mampu dan lingkungan masyarakat yang sebenarnya donominan atau mempengaruhinya. Yang lebih tragis lagi, hal tersebut sudah menjadi suatu tradisi dan telah direncanakan oleh orang tua dengan pola pikir yang biasa terjadi yaitu merencanakan mereka setelah lulus SLTA langsung akan dijodohkan atau dinikahkan. Faktor lingkungan dan pergaulan teman sebaya merupakan faktor yang tdak dapat disepelekan karena hal ini akan justru cenderung menjadi faktor pilihan utama, karena dalam hal ini akan banyak terpengaruh kecenderungan kepada temanteman mereka setelah lulus SLTA, dinama dapat langsung bekerja sudah mendapat penghasilan dan di berbagai lowongan pekerjaan yang menjadikan seperti : Supermarket, Pertokoan dan Restauran yang tersebar di wilayah Bogor dan sekitarnya. Fenomena ini jika dibiarkan dan menjadi suatu tradisi yang turun temurun, dan apabila tidak adanya dobrakan perubahan, maka generasi yang akan datang khususnya di wilayah Ciseeng - Bogor akan berakibat fatal, dimana paling tinggi 
Pendidikan nantinya untuk generasi muda hanya lulusan SLTA. Berkembangnya Ilmu Pengetahuan dan Teknologi secara otomatis akan menuntut beberapa tantangan terhadap generasi muda guna memenuhi kebutuhan tenaga kerja di dunia kerja atau permintaan industri yang semakin modern dan global, yang tentunya siap tidak harus dihadapinya, Karena, jika hanya lulusan SLA sekedar hanya berprofesi sebagai Pramuniaga, Pelayan Restauran, atau buruh pabrik dan tidak lagi dapat mampu bersaing dan memenuhi kualifikasi kebutuhan tenaga kerja dipasar global, disamping itu jika mereka masuk kedalam dunia wirausaha, tentunya mereka belum matang dalam Analisa bisnis dan juga manajerialnya. Latar belakang inilah, maka dari Team PKM (Pengabdian Kepada Masyarakat) menyelenggarakan dengan melibatkan sebagian besar siswa dengan topik "Penyuluhan Motivasi Minat Siswa Untuk Melanjutkan Pendidikan Kejenjang Perguruan Tinggi Di SMK FAJAR CISEENG - BOGOR ”

\section{METODE}

Kegiatan PKM (Pengabdian Kepada Masyarakat) yang diselenggarakan, menggunakan metode penyuluhan kepada para siswa-siswi dan diikuti sebanyak 50 (lima puluh) orang siswa-siswi SMK FAJAR - Ciseeng Bogor, yang bertempat di gedung sekolah SMK FAJAR di Jl. AMD No.39, Babakan, Ciseeng - Bogor.

Kegiatan PKM ini dielenggarakan oleh Team Dosen Program Studi Pendidikan Ekonomi, Fakultas Keguruan dan Ilmu Pendidikan - Universitas Pamulang, yang dihadiri oleh Kepala Sekolah dan beberapa staf pengajar dari SMK FAJAR, seperti terlihat pada Gambar 1.

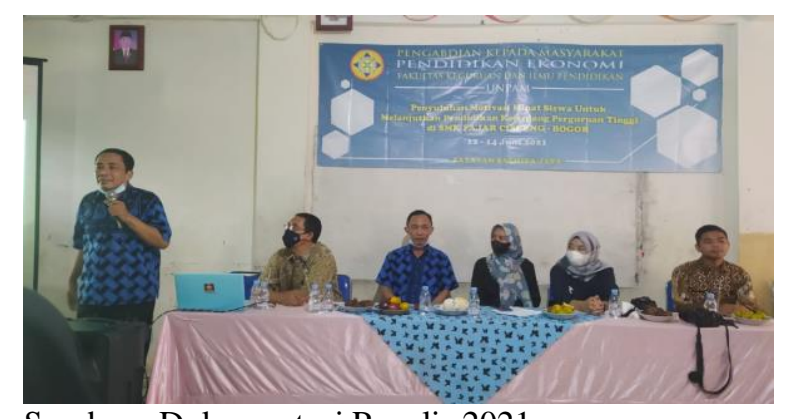

Sumber : Dokumentasi Penulis 2021

Gambar 1: Team Dosen Pengabdian Kepada Masyarakat.

Kegiatan PKM diselenggarakan dengan agenda sebagai berikut :

1. Persiapan, yang meliputi perencanaan sampai kepada pengurusan perizinan kegiatan terkait..

2. Pembukaan,

3. Penyuluhan, den.gan memberikan materi dari beberapa hal dengan melalui presentasi oleh dosen Universitas Pamulang sebagai nara sumber kepada para siswa-siswi SMK FAJAR, tentang : 
a. Bagaimana pengertian secara detail yang berkaitan dengan kecerdasan emosional dan memotivasi diri.

b. Memahami dari Indikator dan Variabel Lingkungan Sosial pada masyarakat.

4. Diskusi, yang merupakan sesi tanya jawab antara siswa dengan pemateri.

5. Evaluasi kegiatan PKM

6. Doa dan penutup

Dengan Susunan panitia pelaksana PKM sebagai berikut :

Ketua : Edi Mulyanto

Anggota :

1. Jumino,

2. Tutug Srijatmiko,

3. Ade Holisoh,

4. Sri Rahayu

Dan dibantu oleh beberapa mahasiswa Universitas Pamulang.

\section{HASIL DAN PEMBAHASAN}

SMK FAJAR merupakan salah satu sekolah yang lokasinya terletak di tepian kota Bogor dan juga Kota Tangerang Selatan. Populasi penduduk di wilayah tersebut masih tergolong minim SDM yang menyelesaikan pendidikan hingga perguruan tinggi, Selain berpencaharian sebagai pedagang dan buruh, mayoritas penduduknya bekerja sebagai karyawan pada super market dan toko di sekitar wilayah tersebut. Tidak jarang masyarakatnya menikah dini pada usia yang sangat muda. Pendidikan tinggi nampaknya belum disadari dan dianggap penting bagi para generasi mudanya. Latar belakang inilah yang menjadi salah satu pertimbangan para dosen Pendidikan Ekonomi Universitas Pamulang untuk mengadakan PKM (Pengabdian Kepada masyarakat).

Kegiatan PKM ini diselenggarakan berjalan dengan lancar dan mendapat tanggapan yang positif dari jajaran staf pengajar maupun Pimpinan SMK FAJAR. Terlihat pula siswasiswi mengikuti kegiatan PKM ini dengan baik dan mereka nampak begitu antausias. Kegiatan ini dapat menjadi tambahan informasi berharga bagi siswa-siswi yang ternyata selama ini belum mereka dapatkan. Diharapkan kegiatan ini akan dapat merangsang mereka setelah lulus, untuk melanjutkan pendidikan ke jenjang pendidikan tinggi.

Pemateri dan presentasi dari beberapa dosen terlihat seperti pada Gambar 2 dan pada Gambar 3. 


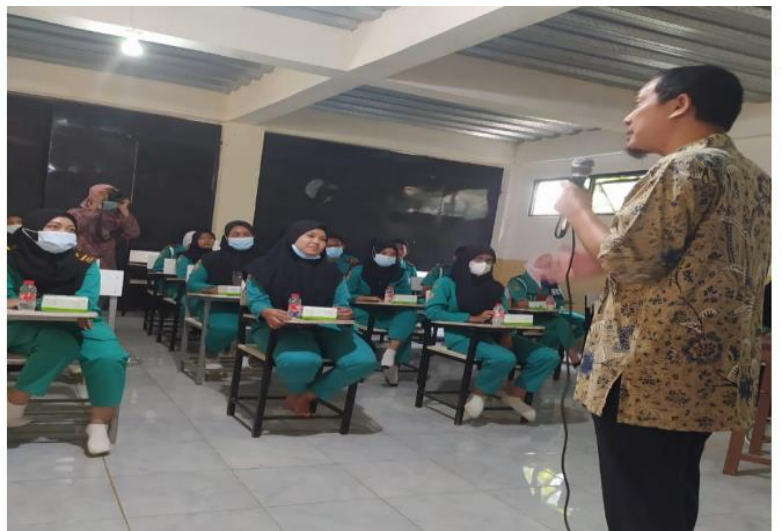

Sumber : Dokumen Penulis. 2021

Gambar 2. Peserta PKM, dengan antausias menyimak materi yang telah disampaikan.

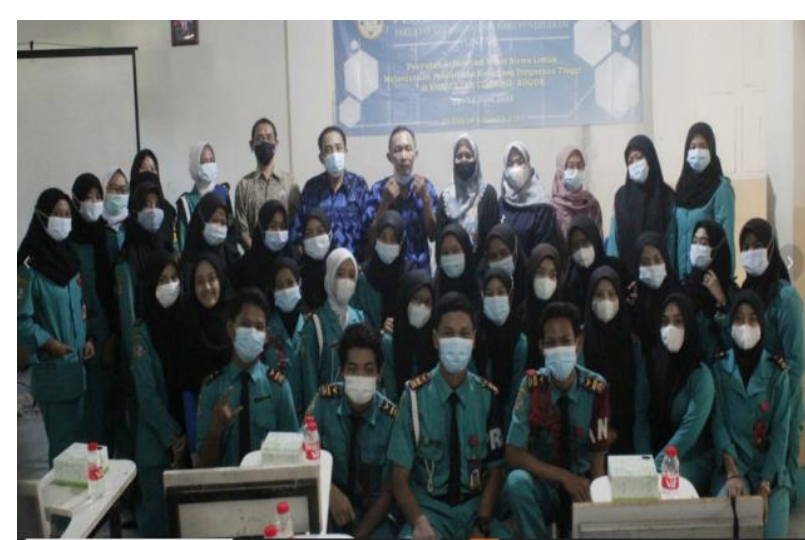

Sumber : Dokumen Penulis 2021

Gambar 3 : Peserta PKM, melakukan photo bersama dengan para Dosen.

Pelaksanaan PKM ini sekaligus menjadi ajang interaksi langsung melalui diskusi interaktif antara dosen pemateri dengan para siswa peserta yang mengikuti penyuluhan. Pemateri berusaha memberikan pemahaman sekaligus membangkitkan ketertarikan kepada siswa akan pentingnya pendidikan yang lebih tinggi lagi untuk mempersiapkan masa depan mereka menuju kehidupan yang lebih baik lagi. Berbagai pengalaman dan latar belakang masing-masing pemateri, disampaikan di hadapan peserta. Hal ini diharapkan dapat menjadi suri tauladan bagi siswa-siswi dalam proses mencari dan menimba ilmu pengetahuan untuk bekal menghadapi masa depan mereka kelak di era yang semakin maju.

Penekanan pada materi penyuluhan ini adalah bagaimana menumbuhkan minat dan motivasi siswa-siswi setelah lulus SLTA agar termotivasi keinginan yang besar dapat melanjutkan pendidikan ke jenjang perguruan tinggi sesuai pilihan jurusan yang mereka inginkan. Pemateri menekankan betapa pentingnya ilmu pengetahuan. Dan disampaikan pula bahwa usaha yang bisa ditempuh untuk memepersiapkan diri guna merubah kehidupan yang lebih baik masa depan adalah melalui pendidikan.

Selain itu, siswa juga diberikan pemahaman tentang pentingnya wirausaha. Selain dijelaskan pentingnya wirausaha dalam pertumbuhan perekonomian sebuah bangsa, juga berusaha menumbuhkan minat untuk meningkatkan ketrampilan yang perlu dimiliki oleh seseorang agar dapat memulai berwirausaha dengan baik dan benar. Pengetahuan berwirausaha yang baik perlu dipersiapkan melalui jenjang pendidikan di perguruan tinggi. Perguran tinggi merupakan sarana untuk membentuk pola pikir mahasiswanya menjadi generasi yang siap 
menghadapi berbagai tantangan di masa mendatang. Sebagaimana yang dikatakan oleh Josep A. Shumpeter bahwa untuk menunjang pertumbuhan perekonomian yang terus meningkat di suatu negara, diperlukan banyak pengusaha.

Tidak dipungkiri bahwa masih banyak generasi masa kini setelah selesai menempuh pendidikan di perguruan tinggi berkeinginan menjadi karyawan/ pegawai. Menjadi pegawai dianggap zona paling aman dan nyaman bagi masa depan mereka kelak. Selain menjadi pegawai negeri, sebagian mereka cenderung berminat menjadi karyawan di perusahaan swasta. Pemikiran latar belakang mereka menganggap bahwa bekerja merupakan solusi untuk memenuhi kebutuhan hidup di masa mendatang. Alhasil dengan berbekal pengetahuan yang relative minim, mereka mencari lowongan pekerjaan di perusahaan retail, supermarket atau UMKM. Padahal pada kenyataannya tidak banyak dunia usaha yang juga mampu bertahan lama dan exis selamanya.

Disisi lain, peluang untuk menjadi pegawai negeri juga terbatas jumlahnya. Peminat yang setiap tahun bertambah, peluang yang ada di pemerintah terbatas dan tidak mampu mengakomodir seuluruhnya. Peluang yang ada juga syarat dengan kualifikasi tertentu yang membutuhkan pendidikan tinggi dan proses yang panjang dan relative lama. Meledaknya lulusan SLTA dan perguruan tinggi setiap tahunnya, tidak akan mampu di tampung seluruhnya oleh pemerintah maupun dunia usaha yang ada. Kendala lain, biasanya di perusahaan menuntut kualifikasi tertentu, tenaga yang sangat terbatas dan syarat akan tenaga yang memiliki pengalaman yang siap kerja.

Lulusan SLTA faktanya saat ini di lapangan belum mampu memenuhi kebutuhan tenaga kerja yang dibutuhkan dunia usaha. Ketrampilan yang terbatas dan minimnya pendidikan seseorang menjadi pertimbangan amat penting bagi dunia bisnis yang kompetitif seperti saat ini. Perusahaan dituntut mengikuti perkembangan teknologi dan peradaban kehidupan manusia yang menuntut serba instan dan modern. Sudah barang tentu kondisi ini membuat dunia usaha meninggalkan cara-cara konvensional. Selain mengikuti perkembangan zaman, perusahaan berorientasi pada profit. Dengan berbagai upaya perusahaan akan melakukan efisiensi dan efektifitas dalam setiap operasionalnya.

Fenomena tersebut diatas, fungsi dan perannya diambil oleh perguruan tinggi, dalam rangka mempersiapkan dan mencetak tenaga terampil dan siap kerja. Perguruan tinggi dianggap sebagai mesin pencetak generasi yang mampu bersaing baik secara nasional maupun internasional. Perguruan 
tinggi yang mampu mencetak tenaga terampil dan cakap, serta lulusannya banyak terserap di dunia kerja akan menjadi pilihan masyarakat untuk menimba ilmu. Kondisi perekonomian yang saat ini mengalami kontraksi, menjadi masalah baru bagi masyarakat. Daya beli yang rendah menjadi salah satu faktor menurunnya minat dan perkembangan masyarakat yang ingin melanjutkan pendidikan tinggi.

Faktanya di lapangan saat ini banyak perusahaan yang terpaksa harus merumahkan dan bahkan mengurangi karyawannya, karena operasional usaha yang sudah tidak mampu lagi bertahan. Perusahaan yang sudah tidak mampu lagi membiayai operasionalnya, terpaksa harus tutup. Persoalan baru yang timbul adalah jumlah pengangguran di usia produktif. Menumbuhkan minat berwirausaha menjadi hal penting yang terus perlu ditumbuhkan di kalangan generasi muda. Banyak di kalangan generasi muda dan bahkan kebenyakan orang menganggap untuk dapat berwirausaha terkendala pada modal awalnya. Namun sebenarnya factor yang utama yang dibutuhkan adalah kemampuan menciptakan sesuatu yang baru.

Menurut Peter F. Drucker bahwa yang dimaksud kewirausahaan adalah kemampuan menciptakan sesuatu yang baru dan beda. Jadi factor utamanya semata-mata bukan karena modal berupa uang. Uang sebagai modal memang sangat penting untuk dapat beroperasinya sebuah bisnis atau usaha. Tetapi ide atau gagasan baru menciptakan usaha merupakan hal yang tidak kalah penitngnya. Usaha yang semata-mata mengandalkan modal dan tanpa diimbangi ide bisnis yang menarik dan menjual, akan membuat usaha itu tidak mampu bertahan lama.

Kondisi demikian yang kurang disadari oleh masyarakat dan generasi muda khususnya. Mayoritas usaha yang tidak mampu bersaing, lama kelamaan akan tutup. Mempersiapkan calon-calon wirausahawan tangguh yang terampil dan mampu bersaing memerlukan waktu panjang. Perguruan tinggi dituntut selalu mengikuti perkembangan teknologi dalam mempersiapkan calon pengusaha yang inovatif dan mampu bersaing di kancah local maupun internasional. Selain itu, perguruan tinggi juga dituntut mampu mengakomodir daya beli masyarakat yang menurun.

\section{Universitas Pamulang dengan} menghasilkan lulusan yang cakap dan dibutuhkan pasar, mampu menjadi solusi bagi masyarakat utamanya golongan ekonomi lemah. Biaya kuliah yang relative murah dan terjangkau bagi masyarakat bawah, kini semakin diminati masyarakat dari seluruh penjuru tanah air. Universitas 
Pamulang memiliki banyak dosen yang memiliki pengalaman luas dan memiliki komitmen tinggi serta integritas keilmuan setiap tahun mampu melahirkan lulusan yang kompeten sesuai bidang pendidikannya telah tersebar luas di seluruh tanah air.

Lulusan Universitas Pamulang tidak hanya mencetak calon karyawan terampil dan cakap yang dibutuhkan dunia usaha saja, namun lulusannya juga banyak yang menjadi pengusaha sukses dan sebagai pejabat pemerintahan yang tersebar luas di daerah maupun pusat di seluruh penjuru tanah air. Kampus Universitas Pamulang yang tersebar di beberapa tempat, menjadi alternative pilihan utama bagi masyarakat ekonomi lemah dan masyarakat dapat memilih jurusan sesuai minatnya serta pilihan kampusnya menyesuaikan dengan lokasi masing-masing dari tempat tinggal maupun lokasi dimana mereka bekerja sehari-harinya.

\section{KECERDASAN EMOSIONAL}

Penekanan pada materi penyuluhan ini adalah bagaimana menumbuhkan minat dan motivasi siswa-siswi setelah lulus SLTA agar termotivasi keinginan yang besar dapat melanjutkan pendidikan ke jenjang perguruan tinggi sesuai pilihan jurusan yang mereka inginkan. Pemateri menekankan betapa pentingnya ilmu pengetahuan. Dan disampaikan pula bahwa usaha yang bisa ditempuh untuk memepersiapkan diri guna merubah kehidupan yang lebih baik masa depan adalah melalui pendidikan.

Selain itu, siswa juga diberikan pemahaman tentang pentingnya wirausaha. Selain dijelaskan pentingnya wirausaha dalam pertumbuhan perekonomian sebuah bangsa, juga berusaha menumbuhkan minat untuk meningkatkan ketrampilan yang perlu dimiliki oleh seseorang agar dapat memulai berwirausaha dengan baik dan benar. Pengetahuan berwirausaha yang baik perlu dipersiapkan melalui jenjang pendidikan di perguruan tinggi. Perguran tinggi merupakan sarana untuk membentuk pola pikir mahasiswanya menjadi generasi yang siap menghadapi berbagai tantangan di masa mendatang. Sebagaimana yang dikatakan oleh Josep A. Shumpeter bahwa untuk menunjang pertumbuhan perekonomian yang terus meningkat di suatu negara, diperlukan banyak pengusaha.

Tidak dipungkiri bahwa masih banyak generasi masa kini setelah selesai menempuh pendidikan di perguruan tinggi berkeinginan menjadi karyawan/ pegawai. Menjadi pegawai dianggap zona paling aman dan nyaman bagi masa depan mereka kelak. Selain menjadi pegawai negeri, sebagian mereka cenderung berminat menjadi karyawan di perusahaan swasta. Pemikiran latar belakang mereka menganggap bahwa 
bekerja merupakan solusi untuk memenuhi kebutuhan hidup di masa mendatang. Alhasil dengan berbekal pengetahuan yang relative minim, mereka mencari lowongan pekerjaan di perusahaan retail, supermarket atau UMKM. Padahal pada kenyataannya tidak banyak dunia usaha yang juga mampu bertahan lama dan exis selamanya.

Disisi lain, peluang untuk menjadi pegawai negeri juga terbatas jumlahnya. Peminat yang setiap tahun bertambah, peluang yang ada di pemerintah terbatas dan tidak mampu mengakomodir seuluruhnya. Peluang yang ada juga syarat dengan kualifikasi tertentu yang membutuhkan pendidikan tinggi dan proses yang panjang dan relative lama. Meledaknya lulusan SLTA dan perguruan tinggi setiap tahunnya, tidak akan mampu di tampung seluruhnya oleh pemerintah maupun dunia usaha yang ada. Kendala lain, biasanya di perusahaan menuntut kualifikasi tertentu, tenaga yang sangat terbatas dan syarat akan tenaga yang memiliki pengalaman yang siap kerja.

Lulusan SLTA faktanya saat ini di lapangan belum mampu memenuhi kebutuhan tenaga kerja yang dibutuhkan dunia usaha. Ketrampilan yang terbatas dan minimnya pendidikan seseorang menjadi pertimbangan amat penting bagi dunia bisnis yang kompetitif seperti saat ini. Perusahaan dituntut mengikuti perkembangan teknologi dan peradaban kehidupan manusia yang menuntut serba instan dan modern. Sudah barang tentu kondisi ini membuat dunia usaha meninggalkan cara-cara konvensional. Selain mengikuti perkembangan zaman, perusahaan berorientasi pada profit. Dengan berbagai upaya perusahaan akan melakukan efisiensi dan efektifitas dalam setiap operasionalnya.

Fenomena tersebut diatas, fungsi dan perannya diambil oleh perguruan tinggi, dalam rangka mempersiapkan dan mencetak tenaga terampil dan siap kerja. Perguruan tinggi dianggap sebagai mesin pencetak generasi yang mampu bersaing baik secara nasional maupun internasional. Perguruan tinggi yang mampu mencetak tenaga terampil dan cakap, serta lulusannya banyak terserap di dunia kerja akan menjadi pilihan masyarakat untuk menimba ilmu. Kondisi perekonomian yang saat ini mengalami kontraksi, menjadi masalah baru bagi masyarakat. Daya beli yang rendah menjadi salah satu faktor menurunnya minat dan perkembangan masyarakat yang ingin melanjutkan pendidikan tinggi.

Faktanya di lapangan saat ini banyak perusahaan yang terpaksa harus merumahkan dan bahkan mengurangi karyawannya, karena operasional usaha yang sudah tidak mampu lagi bertahan. Perusahaan yang sudah tidak mampu lagi membiayai 
operasionalnya, terpaksa harus tutup. Persoalan baru yang timbul adalah jumlah pengangguran di usia produktif. Menumbuhkan minat berwirausaha menjadi hal penting yang terus perlu ditumbuhkan di kalangan generasi muda. Banyak di kalangan generasi muda dan bahkan kebenyakan orang menganggap untuk dapat berwirausaha terkendala pada modal awalnya. Namun sebenarnya factor yang utama yang dibutuhkan adalah kemampuan menciptakan sesuatu yang baru.

Menurut Peter F. Drucker bahwa yang dimaksud kewirausahaan adalah kemampuan menciptakan sesuatu yang baru dan beda. Jadi factor utamanya semata-mata bukan karena modal berupa uang. Uang sebagai modal memang sangat penting untuk dapat beroperasinya sebuah bisnis atau usaha. Tetapi ide atau gagasan baru menciptakan usaha merupakan hal yang tidak kalah penitngnya. Usaha yang semata-mata mengandalkan modal dan tanpa diimbangi ide bisnis yang menarik dan menjual, akan membuat usaha itu tidak mampu bertahan lama.

Kondisi demikian yang kurang disadari oleh masyarakat dan generasi muda khususnya. Mayoritas usaha yang tidak mampu bersaing, lama kelamaan akan tutup. Mempersiapkan calon-calon wirausahawan tangguh yang terampil dan mampu bersaing memerlukan waktu panjang. Perguruan tinggi dituntut selalu mengikuti perkembangan teknologi dalam mempersiapkan calon pengusaha yang inovatif dan mampu bersaing di kancah local maupun internasional. Selain itu, perguruan tinggi juga dituntut mampu mengakomodir daya beli masyarakat yang menurun.

Universitas Pamulang dengan menghasilkan lulusan yang cakap dan dibutuhkan pasar, mampu menjadi solusi bagi masyarakat utamanya golongan ekonomi lemah. Biaya kuliah yang relative murah dan terjangkau bagi masyarakat bawah, kini semakin diminati masyarakat dari seluruh penjuru tanah air. Universitas Pamulang memiliki banyak dosen yang memiliki pengalaman luas dan memiliki komitmen tinggi serta integritas keilmuan setiap tahun mampu melahirkan lulusan yang kompeten sesuai bidang pendidikannya telah tersebar luas di seluruh tanah air.

\section{Lulusan Universitas Pamulang tidak} hanya mencetak calon karyawan terampil dan cakap yang dibutuhkan dunia usaha saja, namun lulusannya juga banyak yang menjadi pengusaha sukses dan sebagai pejabat pemerintahan yang tersebar luas di daerah maupun pusat di seluruh penjuru tanah air. Kampus Universitas Pamulang yang tersebar di beberapa tempat, menjadi alternative pilihan utama bagi masyarakat ekonomi 
lemah dan masyarakat dapat memilih jurusan sesuai minatnya serta pilihan kampusnya menyesuaikan dengan lokasi masing-masing dari tempat tinggal maupun lokasi dimana mereka bekerja sehari-harinya.

\section{MINAT MELANJUTKAN}

\section{PENDIDIKAN KE JENJANG}

\section{PERGURUAN TINGGI}

\section{a. Minat}

Minat merupakan hasrat dalam diri seseorang terhadap sesuatu hal. Minat berperan sangat penting pada diri seseorang yang akan menimbulkan motivasi. Untuk dapat mewujudkan cita-cita yang diinginkan, pada hakekatnya diawali dengan minat dan motivasi untuk melakukannya dalam bentuk tindakan secara nyata. Minat merupakan factor pendorong timbulnya motivasi bagi seseorang untuk melanjutkan pendidikan tinggi. Dengan motivasi yang kuat, akan mendorong semangat yang pantang menyerah selama yang bersangkutan berjuang meraih cita-cita.

\section{b. Faktor-Faktor yang Mempengaruhi}

\section{Minat Melanjutkan Pendidikan Ke}

\section{Jenjang Perguruan Tinggi}

1) Faktor Internal, antara lain : keluarga, orang tua

Keluarga dan orang tua memiliki peran penting dalam mempengaruhi terbentuknya karakter seseorang. Orang tua merupakan figur yang menjadi contoh dan panutan seharihari terutama di dalam rumah tangga yang akhirnya dapat mempengaruhi perkembangan kejiwaan seseorang sewaktu-waktu atau bahkan sepanjang hidupnya.

2) Faktor Eksternal, antara lain : lingkungan dan masyarakat

$\begin{array}{lrr}\begin{array}{l}\text { Lingkungan dan } \\ \text { merupakan komunitas }\end{array} & \begin{array}{r}\text { mang } \\ \text { inheren }\end{array} \text { dan } & \begin{array}{r}\text { berpotensi } \\ \text { mempengaruhi }\end{array} \\ \text { psikologis bagi } & \text { seseorang. } \\ \text { Lingkungan pergaulan, dapat } \\ \text { mempengaruhi pola pikir dan } \\ \text { tindakan seseorang. }\end{array}$

\section{c. Indikator Minat Melanjutkan}

\section{Pendidikan Ke Jenjang Perguruan}

\section{Tinggi}

Untuk dapat mewujudkan cita-cita melanjutkan pendidikan ke jenjang perguruan tinggi, secara garis besar, maka seorang siswa memiliki tahapan sebagai berikut :

\section{Attention (perhatian)}

Dimulai dari perhatian seseorang terhadap sesuatu hal yang dianggap baru, dapat menyebabkan rasa keingintahuan itu timbul secara tibatiba dan mampu mempengaruhi psikologis seseorang menjadi timbul minat. 
2. Interest (minat)

Perhatian akan mendorong seseorang terhadap sesuatu hal menjadilan sebuah minat seseorang terhadap sesuatu yang menimbulkan rangsangan

\section{Desire (keinginan)}

Minat yang kuat akan merubah pola pikir seseorang menjadi keinginan untuk dapat dilakukannya

\section{Action (tindakan)}

Keinginan yang kuat pada akhirnya dapat diwujudkan dalam bentuk tindakan nyata.

\section{KESIMPULAN}

Berkembangnya Ilmu Pengetahuan dan Teknologi menuntut tantangan generasi muda terhadap kebutuhan tenaga kerja, yang siap menghadapi persaingan era globalisasai. Karena, jika hanya lulusan SLA sekedar hanya berprofesi sebagai Pramuniaga atau Pelayan Restauran dan tidak dapat mampu bersaing dan memenuhi kualifikasi kebutuhan tenaga kerja dipasar global. Latar belakang inilah, maka PKM (Pengabdian Kepada Masyarakat) ini diselenggarakan dengan melibatkan sebagian besar siswa dengan topik "Penyuluhan Motivasi Minat Siswa Untuk Melanjutkan Pendidikan Kejenjang Perguruan Tinggi Di SMK FAJAR CISEENG - BOGOR ".
Kegiatan PKM ini diselenggarakan berjalan dengan lancar dan mendapat tanggapan yang positif dari jajaran staf pengajar maupun Pimpinan SMK FAJAR. Terlihat pula siswa-siswi mengikuti kegiatan PKM ini dengan baik dan mereka nampak begitu antausias. Kegiatan ini dapat menjadi tambahan informasi berharga bagi siswasiswi yang ternyata selama ini belum mereka dapatkan. Diharapkan kegiatan ini akan dapat merangsang mereka setelah lulus SLTA, dapat melanjutkan pendidikan ke jenjang pendidikan tinggi.

Penekanan pada materi penyuluhan ini adalah bagaimana menumbuhkan minat dan motivasi siswa-siswi setelah lulus SLTA agar termotivasi keinginan yang besar dapat melanjutkan pendidikan ke jenjang perguruan tinggi sesuai pilihan jurusan yang mereka inginkan. Pemateri menekankan betapa pentingnya ilmu pengetahuan. Dan disampaikan pula bahwa usaha yang bisa ditempuh untuk memepersiapkan diri guna merubah kehidupan yang lebih baik masa depan adalah melalui pendidikan.

Selain itu, siswa juga diberikan pemahaman tentang pentingnya wirausaha. Selain dijelaskan pentingnya wirausaha dalam pertumbuhan perekonomian sebuah bangsa, juga berusaha menumbuhkan minat untuk meningkatkan ketrampilan yang perlu dimiliki oleh seseorang agar dapat memulai 
berwirausaha dengan baik dan benar. Peminat yang setiap tahun bertambah, Pengetahuan berwirausaha yang baik perlu dipersiapkan melalui jenjang pendidikan di perguruan tinggi. Perguran tinggi merupakan sarana untuk membentuk pola pikir mahasiswanya menjadi generasi yang siap menghadapi berbagai tantangan di masa mendatang. Sebagaimana yang dikatakan oleh Josep A. Shumpeter bahwa untuk menunjang pertumbuhan perekonomian yang terus meningkat di suatu negara, diperlukan banyak pengusaha.

Tidak dipungkiri bahwa masih banyak generasi masa kini setelah selesai menempuh pendidikan di perguruan tinggi berkeinginan menjadi karyawan/ pegawai. Menjadi pegawai dianggap zona paling aman dan nyaman bagi masa depan mereka kelak. Selain menjadi pegawai negeri, sebagian mereka cenderung berminat menjadi karyawan di perusahaan swasta. Pemikiran latar belakang mereka menganggap bahwa bekerja merupakan solusi untuk memenuhi kebutuhan hidup di masa mendatang. Alhasil dengan berbekal pengetahuan yang relative minim, mereka mencari lowongan pekerjaan di perusahaan retail, supermarket atau UMKM. Padahal pada kenyataannya tidak banyak dunia usaha yang juga mampu bertahan lama dan exis selamanya.

Disisi lain, peluang untuk menjadi peluang yang ada di pemerintah terbatas dan tidak mampu mengakomodir seuluruhnya. Peluang yang ada juga syarat dengan kualifikasi tertentu yang membutuhkan pendidikan tinggi dan proses yang panjang dan relative lama. Meledaknya lulusan SLTA dan perguruan tinggi setiap tahunnya, tidak akan mampu di tampung seluruhnya oleh pemerintah maupun dunia usaha yang ada. Kendala lain, biasanya di perusahaan menuntut kualifikasi tertentu, tenaga yang sangat terbatas dan syarat akan tenaga yang memiliki pengalaman yang siap kerja.

Lulusan SLTA faktanya saat ini di lapangan belum mampu memenuhi kebutuhan tenaga kerja yang dibutuhkan dunia usaha. Ketrampilan yang terbatas dan minimnya pendidikan seseorang menjadi pertimbangan amat penting bagi dunia bisnis yang kompetitif seperti saat ini. Perusahaan dituntut mengikuti perkembangan teknologi dan peradaban kehidupan manusia yang menuntut serba instan dan modern. Sudah barang tentu kondisi ini membuat dunia usaha meninggalkan cara-cara konvensional. Selain mengikuti perkembangan zaman, perusahaan berorientasi pada profit. Dengan berbagai upaya perusahaan akan melakukan efisiensi dan efektifitas dalam setiap operasionalnya. pegawai negeri juga terbatas jumlahnya. 


\section{REFERENSI}

Ahmadi, Abu. (2013). Psikologi Belajar. Jakarta: Rineka Cipta.

Amrizal, Ahmad (2013), Undang-undang RI No.20 tahun 2003 tentang Sistem Pendidikan Nasional : http/slideshare .net/ahmadrizal/01 UU-no-20 tahu 2003 tentang-sistem-pendidikan nasional ( 12 Januari 2016 ).

Effendi Mujiono dan Mursillah. (2018). Korelasi Tingkat Perhatian Orang Tua dan kemandirian belajar dengan prestasi Belajar Siswa. Jurnal Ilmiah Multi Sciences 17-23

Goleman, Daniel. (2017). Emotional Intelligence. Jakarta: PT. Gramedia Pustaka Utama.

Kharisma, Nabila. (2015). Pengaruh Motivasi , Prestasi Belajar, Satatus Sosial Ekonomi Orang Tua dan
Lingkungan Teman Sebaya terhadap minat melanjutkan Pendidikan Ke Jenjang Perguruan Tinggi pada Siswa Kelas XII Kompetensi Keahlian Akuntansi di SMK Negeri Se Kota Semarang tahun ajaran 2014/2015. Skripsi Universitas Negeri Semarang.

Khodijah, Nyanyu. (2014). Psikologi Pendidikan. Jakarta: Rajawali Pers.

Slameto. (2013). Belajar dan Faktor-faktor yang mempengaruhi . Jakarta :

\section{Rineka Cipta.}

Sudirman .(2011). Interaksi dan Motivasi belajar mengajar. Jakarta Rajawali Pers.

Uno Hamzah, (2011). Teori Motivasi dan pengukuranya. Jakarta : Bumi Aksara.Sudirman .(2011). Interaksi dan Motivasi belajar mengajar. Jakarta Rajawali Pers. 
Jurnal Loyalitas Sosial

Vol. 3 No. 2 September 2021
Journal of Community Services in Humanities and Social Sciences p-ISSN 2655-9072 | e-ISSN 2686-1380 